\title{
Glassy-winged sharpshooters expected to increase plant disease
}

\author{
Alexander H. Purcell $\square$ Stuart R. Saunders
}

\begin{abstract}
As it moves through California, the new pest known as glassy-winged sharpshooter (GWSS) may signiffcantly increase the spread of plant diseases caused by the bacterium Xylella fastidiosa. The bacterium causes Pierce's disease of grapevines, almond leaf scorch and the newly recognized oleander leaf scorch disease. Currently, almond leaf scorch is a minor problem for California's almonds, but if GWSS becomes established in significant numbers in or near almond orchards, it might increase the incidence of almond leaf scorch. Our studies show that GWSS and two other sharpshooter species can transmit $X$. fastidiosa from diseased oleanders to healthy oleanders. GWSS also can transmit Pierce's disease strains of the bacterium from grapevine to grapevine and to almond trees. The oleander strain of the bacterium did not infect grapevines, but the ability of GWSS to transmit Pierce's disease strains may increase the spread of this lethal grapevine disease in vineyards bordering citrus orchards or other habitats where invading GWSS may establish permanent populations.
\end{abstract}

The continuing spread of the glassywinged sharpshooter (GWSS) within California increases the likelihood that plant diseases caused by the bacterium Xylella fastidiosa will become more prevalent. The same strains of $X$. fastidiosa can cause Pierce's disease of grapevines, almond leaf scorch and alfalfa dwarf disease (Davis et al. 1980; Hewitt et al. 1946). Recent studies proved that a different strain of this bacterium causes the newly recognized ole- ander leaf scorch disease (Purcell et al. 1999). GWSS is already known to transmit X. fastidiosa strains that cause two serious diseases in the Southeast: phony disease of peach (Turner and Pollard 1949) and Pierce's disease (Adlerz and Hopkins 1979), but the transmission efficiency of GWSS as a Pierce's disease vector has not been assessed.

In this paper, we report tests of glassy-winged sharpshooter, Homalodisca coagulata, as a vector of $X$. fastidiosa to oleander, grape and almond. We also tested two other sharpshooter species that are native to California as vectors of $X$. fastidiosa on oleander.

The GWSS is a leafhopper in the sharpshooter subfamily, whose members primarily feed on sap of the waterconducting tissues (xylem) of plants. All members of this subfamily, as well as some other xylem sap-feeders such as spittlebugs, are vectors of the xylemlimited bacterium $X$. fastidiosa. However, the efficiency of transmission of particular vector species varies according to the vector and plant species involved. For example, the vectors most closely linked to the spread of Pierce's disease in the Central Valley are primarily grass-feeding sharpshooters such as the green sharpshooter, Draeculacephala minerva, and red-headed sharpshooter, Carneocephala fulgida. Grass-feeding sharpshooters are much less efficient in transmitting $X$. fastidiosa to grape, but more abundant in the valley than the blue-green sharpshooter (BGSS), Graphocephala atropunctata, which commonly feeds on grape in coastal California.

To assess the Xylella-transmitting ability of the sharpshooters, we collected GWSS and its close relative, the smoke tree sharpshooter (STSS), Homalodisca lacerta, from ornamental shrubs in Orange County and from citrus in Riverside. We collected BGSS from habitats in Anderson Valley. Because some of the insects might have been naturally infective, we confined groups of sharpshooters on oleander or grape "pretest" plants, as appropriate, for several days prior to further transmission tests. Later assessments of the pretest plants (by attempting to culture $X$. fastidiosa) gave no indication that the test insects carried strains of X. fastidiosa that might infect either grape or oleander. We then confined the insects for 2 to 4 days on oleanders with symptoms of leaf scorch or on grapevines with Pierce's disease symptoms. Following this opportunity for the sharpshooters to acquire $X$. fastidiosa, we placed them on either healthy oleander or grape, respectively, to allow them to inoculate the test plants with $X$. fastidiosa. We kept the test plants in a protected greenhouse for 4 to 12 months to assess disease symptoms. Then we attempted to culture the bacterium from leaf petioles or midveins to identify which plants had become infected.

In tests with a single adult per grapevine, we confirmed that GWSS transmitted X. fastidiosa from grape to 3 of 15 plants in one experiment and 1 of 6 grapevines in another. When the number of adults was increased to two per plant, 4 of 9 test plants became infected. The results of all three trials were consistent with $15 \%$ to $20 \%$ transmission efficiency for individual insects. In contrast, BGSS usually transmits to grape at rates exceeding $90 \%$ under these conditions (Purcell and Finlay 1979). In three separate experiments to evaluate the GWSS efficiency of transmitting Pierce's disease from grape to healthy almond, only 1 of a total of 42 GWSS transmitted X. fastidiosa to almond, indicating a transmission rate as low as $2 \%$.

In other experiments, we showed that BGSS, GWSS and its close relative the smoke tree sharpshooter (STSS), 


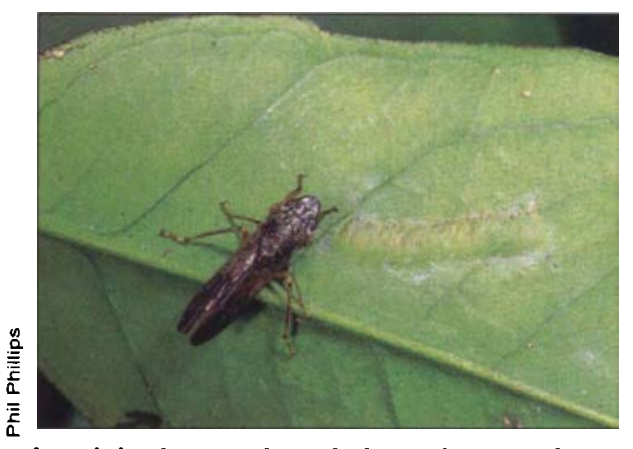

An adult glassy-winged sharpshooter sits next to its egg mass, which is on the underside of the leaf.

Homalodisca lacerta, transmitted X. fastidiosa from oleander to oleander, causing the oleander leaf scorch disease (Purcell et al. 1999). Groups of four BGSS per plant infected all four test oleanders with $X$. fastidiosa. Groups of two or three GWSS transmitted to all three test plants in one experiment, but not to five test plants when caged singly on test plants in another trial. STSS infected 2 of 8 plants in single insect transmission trials, but in another test with three or four insects per plant, none of eight plants became infected with $X$. fastidiosa. The differences in transmission success among separate trials were most likely caused by differences in how well diseased plants served as acquisition hosts. We concluded that GWSS and other sharpshooters are capable of transmitting X. fastidiosa to oleander at a rate that can account for the observed spread of oleander leaf scorch disease in locations where the new oleander disease has been noticed. Low transmission rates can result in substantial disease spread if vector populations or rates of movement from plant to plant are high.

We were also able to readily infect oleanders without sharpshooters by probing a green stem with a fine needle through a droplet of suspended $X$. fastidiosa cells cultured from oleanders (Purcell et al. 1999). Three to 6 months after we had inoculated the oleanders, we detected the bacterium in all but 2 of 25 oleanders. Two other plant species in the same family as oleander (dogbane family) - large periwinkle (Vinca major) and Madagascar periwinkle (Catharanthus rosea) - developed systemic (moving within the xylem system) infections after needle inoculation. Madagascar periwinkle had symptoms of rapid wilt, but only 9 to 11 months after inoculation. Large periwinkle developed symptoms of marginal leaf scorch after 7 to 8 months in the greenhouse. No cases of seriwinkle wilt or leaf scorch have yet seen reported from areas of Southern Zalifornia where oleander leaf scorch las become apparent. It is possible that greenhouse conditions accelerate the development of disease symptoms in periwinkles, and that disease symptoms do not normally appear in periwinkles growing outdoors.

The newly described strain of $X$. fastidiosa from oleander does not appear to infect grape. We did not detect the bacterium in any of 13 grape test plants inoculated by needle with an oleander strain, although normally over $90 \%$ of grapevines inoculated with Pierce's disease strains using this method develop Pierce's disease (our unpublished data). Moreover, none of three 'Lovell' peach seedlings, six olive plants, and three seedlings of California blackberry became infected after multiple needle inoculations with an oleander strain, but all six of the oleander seedling inoculated as positive controls developed bacterial populations and symptoms of leaf scorch (Purcell et al. 1999). In tests where we inoculated 'Peerless' almond seedlings with oleander strains of $X$. fastidiosa by needle puncture, we later cultured X. fastidiosa from 7 of 10 inoculated plants after 100 days and after another 360 days from 1 of 6 of previously positive almond plants that remained positive. None of five uninoculated control plants were positive. After more than a year following inoculation, we cultured the bacterium from leaves that were no older than 60 to 90 days, indicating that an oleander strain of $X$. fastidiosa can move systemically within almond. It is not yet clear whether oleander strains can cause disease in almond, as do Pierce's disease strains. Further greenhouse and field trials are in progress.

The recent discoveries of GWSS in citrus groves in the southern Central Valley highlight the need to learn more about this sharpshooter's potential to spread almond leaf scorch disease in Central California habitats. Currently, almond leaf scorch is a minor problem for most of California's almond growers, but known vectors of $X$. fastidiosa are rarely encountered in the state's almond orchards. If GWSS becomes established in significant numbers in or near almond orchards, the documented propensity of GWSS to feed on stone fruits (Turner and Pollard 1959) might dramatically increase the incidence of almond leaf scorch (see page 22 ).

GWSS may also represent a threat as a Pierce's disease vector, especially in vineyards near habitats, such as citrus groves, that are favored by this sharpshooter. GWSS is reported to breed on numerous woody plant species and to overwinter in woodlands in its native region of the southeastern states (Turner and Pollard 1959). Currently, Pierce's disease in Central California occurs most commonly near hay fields and irrigated pastures, and in coastal California near riparian woodlands. If GWSS occupies habitats favorable for its development that are not now inhabited by other vectors of $X$. fastidiosa - such as nonriparian woodlands, crop fields or ornamental landscapes that do not currently harbor sharpshooters - additional types of foci for Pierce's disease and other diseases caused by $X$.

fastidiosa could become important.

A.H. Purcell is Professor and S.R. Saunders is Staff Research Associate in the Division of Insect Biology, Department of Environmental Science, Policy and Management, UC Berkeley.

\section{References}

Adlerz WC and Hopkins DL. 1979. Natural infectivity of two sharpshooter vectors of Pierce's disease of grape in Florida. J Econ Entomol 72: 916-9.

Davis MJ, Thomson SV and Purcell AH. 1980. Etiological role of a xylem-limited bacterium causing Pierce's disease in almond leaf scorch. Phytopathology 70:472-5.

Hewitt WB, Houston BR, Frazier NW and Freitag JH. 1946. Leafhopper transmission of the virus causing Pierce's disease of grape and dwarf of alfalfa. Phytopathology 36:117-28.

Purcell AH and Finlay AH. 1979. Evidence for noncirculative transmission of Pierce's disease bacterium by sharpshooter leafhoppers. Phytopathology 69:393-5.

Purcell AH, Saunders SR, Hendson, M, et al. 1999. Causal role of Xylella fastidiosa in oleander leaf scorch disease. Phytopathology 89:53-58

Turner WF and Pollard HN. 1949. Insect vectors of phony peach disease. Science 109: 87-8.

Turner WF and Pollard HN. 1959. Life histories and behavior of five insect vectors of phony peach disease. U. S. Dept. of Agriculture Technical Bulletin 1188. 